\title{
Groundwater management for sustainable production of drinking water quality in Maâmora
}

D. Belghyti ${ }^{1}$, H. Daifi ${ }^{1}$, A. Alemad ${ }^{1}$, K. Elkharrim ${ }^{1}$, M. Elmarkhi ${ }^{1}$, Y. Souidi ${ }^{1}$, F. Benelharkati ${ }^{1}$, B. Joti ${ }^{1,2}$, Z. Elmoukrifi ${ }^{1}$, A. Ibeda ${ }^{3}$, Y. Azami-Idrissi ${ }^{1}$, S. Baroud ${ }^{1}$, F. Elkhayyat $^{1}$, O. Elrhaouat ${ }^{1}$, S. Sadeq ${ }^{1}$, Y. Taboz ${ }^{1}$, H. Sbai ${ }^{4}$, R. Naser ${ }^{1}$, H. Chigger ${ }^{5}$ $\&$ N. Derwich ${ }^{1}$

${ }^{1}$ Laboratory of Environment and Renewable Energy, Faculty of Sciences, University Ibn Tofail, Kénitra, Morocco

${ }^{2}$ National Office of Drinking Water (ONEP), Kénitra, Morocco

${ }^{3}$ Organization of Development, Sabha, Libya

${ }^{4}$ National Office of Drinking Water, Mechraa Bel Ksiri, Morocco

${ }^{5}$ Society of Solid Waste, Fez, Morocco

\section{Abstract}

The problem of water pollution affects the whole world including groundwater which is more susceptible to contamination by residues of industry, agriculture and domestic wastewater leading to the emergence of many serious epidemic diseases (cholera, typhoid, amoebiasis,...etc).

The purpose of this study is to evaluate the impact of agricultural intensification and discharge of untreated sewage on the physical, chemical and bacteriological water quality of groundwater Maâmora, Kénitra, Morocco.

The physicochemical parameters followed are: $\mathrm{T}^{\circ} \mathrm{C}, \mathrm{pH}, \mathrm{EC}, \mathrm{NH}_{4}^{+}, \mathrm{NO}_{2}^{-}$, $\mathrm{NO}_{3}^{-}, \mathrm{Cl}^{-}, \mathrm{F}^{-}, \mathrm{HCO}_{3}{ }^{-}, \mathrm{SiO}_{2}, \mathrm{SO}_{4}{ }^{2-}$, Boron, Dry Residue, Turbidity, Total Hardness $(\mathrm{TH})$, Dissolved $\mathrm{O}_{2}$, Oxidisability and total and fecal coliforms of raw water from the boreholes.

This study shows that the physicochemical and bacteriological quality of the groundwater which is used as drinking water for the city of Kénitra and adjacent areas is generally good. However, high concentrations of nitrates $\left(\mathrm{NO}_{3}, \mathrm{NO}_{2}\right)$ in 
some wells (over $51.55 \mathrm{mg} / \mathrm{L}$ ) are worrisome because of the serious health consequences (methemoglobinemia).

For sustainable use, policymakers must protect the aquifer against the anarchic development of agriculture and spreading unreasonable amounts of pesticides and fertilizers.

Keywords: drinking water, tablecloth, bacteria, physicochemical, Nitrate, Morocco.

\section{Introduction}

In Morocco groundwater is an important part of the hydraulic heritage of the country REEM [1]. Groundwater, often protected geologically, is exposed to agricultural, industrial or urban pollution.

In this coastal region, in addition to marine disturbances (seawater intrusion), water resources are increasingly threatened by pollution from urban, agricultural, industrial and artisanal origin. Indeed, this urbanization has led to demands for ever increasing water and generated polluted sites that multiply without any protection of the environment. Pollution of groundwater is one of the most disturbing aspects and the use of these waters for food is a health hazard. Given the high demand for water for demographic growth and related industrial development, water pollution is increasing day by day (Laferriere et al. [2]). The World Health Organization (WHO [3]) estimated that $80 \%$ of diseases that affect the world's population are directly related to water, which implies the need to treat the water.

This work focuses on the study of the quality of the groundwater Maâmora, monitoring of physico-chemical and bacteriological parameters of water representing 10 samples is well done to clarify the importance of pollution and determine the cause. Ground water analyzes in the study area were made in Laboratory of the National Office of Drinking Water (ONEP) and in University Ibn Tofaïl, Kénitra, Morocco.

\section{Material and methods study}

\subsection{Area study}

Maâmora which is a $2300 \mathrm{~km}^{2}$ basin is bordered on the north by the region of Sidi Yahia, the tablecloth Tiflète, to the east by the river Beht, and west by the Atlantic sea. North of the study area, the Gharb basin shows a very gentle terrain in its central part. In contrast, in the western and eastern part, its altitude is $20 \mathrm{~m}$. The Maâmora basin has a slope of $6 \%$ to the NNW, culminates in the SE at around 250 meters and has more on the outskirts of Gharb, an altitude of 10 to 30 meters. The overall morphology is a succession of hills and valleys parallel to the shore in a mean direction $\mathrm{N} 030^{\circ} \mathrm{E}$ and $\mathrm{N} 130^{\circ} \mathrm{E}$ locally at 150 . Maâmora is characterized by a well developed river system from West to East. The main rivers are Sebou, Fouarate, Semento, Tiflète, Touirza, Tahrest, Beht and Mellah. The Oued Fouarate with a total length of about $40 \mathrm{~km}$, occupies the western 
valley. The area of its basin is about $285 \mathrm{~km}^{2}$. In its upper reaches, Fouarate river management has a $\mathrm{N} 150^{\circ} \mathrm{E}$, and then curves to the $\mathrm{NW}$ with a mean direction $\mathrm{N} 030^{\circ} \mathrm{E}$ in the downstream portion of his career, to finally throw in the Sebou river (Zouhri and Carlier [4]). The city of Kénitra is located $40 \mathrm{~km}$ north of the capital of the Kingdom of Morocco. It is bounded by the Sebou river in the north, Lake Fouarat in the East and Forest Maâmora in southwest. The objective of this work is to take a sample of 10 wells in 2010 (Table 1, Fig. 1).

Table 1: $\quad$ Drilling studied.

\begin{tabular}{|c|l|l|c|}
\hline Wells Number & Flow (l/s) & Localizations & Profundity(m) \\
\hline W1 & 156 & Ain Sebaa, Kénitra & 120 \\
W2 & 50 & El Menzeh, Kénitra & 135 \\
W3 & 150 & Ain Arris (Ain Sebaa), Kénitra & 110 \\
W4 & 45 & Ahmed Taleb, Kénitra & 117 \\
W5 & 40 & Ain Khadra (Ain Sebaa), Kénitra & 145 \\
W6 & 100 & Ain Taichà (Mehdia), Kénitra & 120 \\
W7 & 100 & Sidi Taibi (Ain Sebaa), Kénitra & 130 \\
W8 & 40 & Sidi Yahia, Kénitra & 140 \\
W9 & 50 & (Ain Sebaa), Kénitra & 146 \\
W10 & 50 & (Ain Sebaa), Kénitra & 123 \\
\hline
\end{tabular}

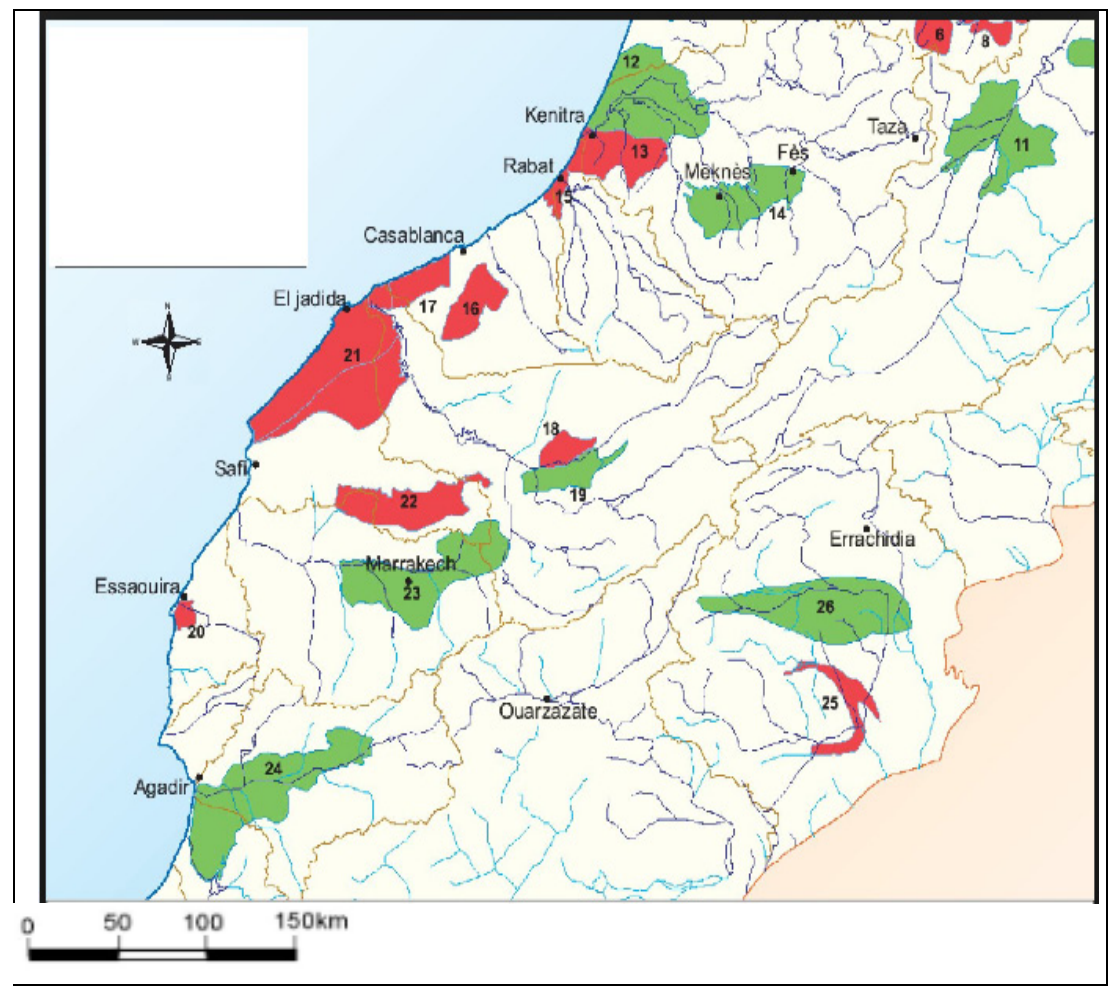

Figure 1: $\quad$ Maâmora (13) and other aquifers of Morocco. 


\subsection{Study methods}

On samples of raw water of Maâmora, we conducted bacteriological (fecal coliforms, total coliforms) and physico-chemical analysis $\left(\mathrm{T}^{\circ} \mathrm{C}, \mathrm{pH}, \mathrm{EC}, \mathrm{NH}^{4+}\right.$, $\mathrm{NO}_{2}^{-}, \mathrm{NO}_{3}^{-}, \mathrm{Cl}^{-}, \mathrm{F}^{-}, \mathrm{HCO}_{3}^{-}, \mathrm{SiO}_{2}, \mathrm{SO}_{4}{ }^{2-}$, Boron, Dry Residue, Turbidity, Total Hardness (TH), Dissolved $\mathrm{O}_{2}$, Oxidisability).

The samples at the pumps are made after buckling tap and extended in order to have a permanent water quality pumping. The water samples are collected in $500 \mathrm{ml}$ bottles kept refrigerated cooler $\left(4^{\circ} \mathrm{C}\right)$ until analysis. The following physico-chemical parameters are performed using the techniques of Rodier [5]. Temperature, the potential $(\mathrm{pH})$ and electrical conductivity (EC) were measured in situ using a portable multiparameter (Consort Type 835C). Nitrate $\left(\mathrm{NO}_{3}{ }^{-}\right)$, Nitrite $\left(\mathrm{NO}_{2}{ }^{-}\right)$, ammonia nitrogen $\left(\mathrm{NH}_{4}^{+}\right)$, Silicate $\left(\mathrm{SiO}_{2}\right)$, Boron $\left(\mathrm{B}^{+}\right)$, Fluoride $\left(\mathrm{F}^{-}\right)$and sulfate $\left(\mathrm{SO}_{4}^{--}\right)$are determined by colorimetric assay using a spectrophotometer (UV/visible Lampa 2). Hardness $(\mathrm{TH})$ is measured by the volumetric method using EDTA. The oxidisability (oxidizable materials: MO) is determined by temperature oxidation in acidic medium. Bicarbonates $\left(\mathrm{HCO}_{3}{ }^{-}\right)$ are analyzed by volumetric titration with $0.1 \mathrm{~N} \mathrm{HCl}$. Chloride $\left(\mathrm{CL}^{-}\right)$is determined by the solution of mercuric nitrate $\left(\mathrm{HgNO}_{3}{ }^{-}\right)$. The title below the oxygen $\left(\mathrm{O}_{2}\right)$ determined by sodium thiosulfate solution $\left(\mathrm{Na}_{2} \mathrm{~S}_{2} \mathrm{O}_{3}\right) 0.2 \mathrm{~N}$. The dry residue determined by evaporation at $105{ }^{\circ} \mathrm{C}$ and weighed for the balance of precision $10^{-4}$. Turbidity (NTU) measured by a turbidimeter: HACH brand. Model $2100 \mathrm{~N}$.

The microbiological groundwater Maâmora is determined by the method of the most probable number (MPN) (Rodier [5]). This method is to inoculate using appropriate decimal sample to analyze a series of tubes containing nutrient broth medium for searching the total flora dilutions. After incubation for $24 \mathrm{~h}$ at $37^{\circ} \mathrm{C}$, the tubes with a disorder are considered positive. The assessment of faecal contamination is achieved by the enumeration of faecal coliforms and faecal streptococci. Total coliforms were counted after incubation for $24 \mathrm{~h}$ to $48 \mathrm{~h}$ at $37^{\circ} \mathrm{C}$, the tubes containing the medium broth lactose bromocresol purple, fitted with a Durham (presumptive test). The positive tubes (lactose fermentation and gas production) are transplanted to a confirmatory test in a selective medium containing bile salts, bile brilliant green broth with a Durham tube, and another tube containing peptone water free indole and then incubated for $24 \mathrm{~h}$ to $48 \mathrm{~h}$ at $44^{\circ} \mathrm{C}$. Gas production in the first and in the second indole, is evidenced by the presence of fecal coliforms.

As for streptococci, their research is done on the Rothe medium at $37^{\circ} \mathrm{C}$ for $24 \mathrm{~h}$ (presumptive test). From tubes positive Rothe, a subculture is performed on middle Litsky at $37^{\circ} \mathrm{C}$ for $24 \mathrm{~h}$ (confirmatory test). The results are expressed as number of organisms per $100 \mathrm{ml}$ following the McCrady statistical table. The results are analyzed by a statistical comparison of the mean test of Duncun [6]. From the $\mathrm{p}<0.05$ level, the test is taken as being significant. 


\section{Results and discussion}

The assessment of the physico-chemical and bacteriological quality of the water Maâmora was followed through the analysis of water collected at the 10 drillings during the February and March 2010.

\subsection{Temperature}

We note that the temperature values remain almost constant (Table 2) and this is due to made that groundwater is protected from solar radiation and the atmosphere.

Table 2: $\quad$ Evolution of the temperature of the water table Maâmora.

\begin{tabular}{|c|c|c|c|c|}
\hline Wells & February & March & Average $\left({ }^{\circ} \mathrm{C}\right)$ & SD \\
\hline W1 & 19.7 & 20.4 & 20.05 & 0.35 \\
W2 & 20.1 & 21.2 & 20.65 & 0.55 \\
W3 & 19.8 & 20.7 & 20.25 & 0.45 \\
W4 & 19.6 & 20.3 & 19.95 & 0.35 \\
W5 & 20 & 20.6 & 20.3 & 0.3 \\
W6 & 19.9 & 20.2 & 20.05 & 0.15 \\
W7 & 21.9 & 20.4 & 21.15 & 0.75 \\
W8 & 20 & 20 & 20 & 0 \\
W9 & 21.8 & 20.6 & 21.2 & 0.6 \\
W10 & 21.4 & 20.1 & 20.75 & 0.65 \\
\hline
\end{tabular}

\section{$3.2 \mathrm{pH}$}

The $\mathrm{pH}$ of the water varies in the study from 6.65 to 7.89 (Table 3). The values obtained are close to neutrality, while referring to the Moroccan standards $(6.5<\mathrm{pH}<8.5)$ for drinking water (Table 19$)$, we note that $100 \%$ of the analyzed waters conform to human consumption. Indeed, the waters of the Maâmora Kénitra do not require $\mathrm{pH}$ adjustment.

Table 3: $\quad$ Evolution of $\mathrm{pH}$ of the water table Maâmora.

\begin{tabular}{|c|c|c|c|c|}
\hline Wells & February & March & Average & SD \\
\hline W1 & 7.35 & 7.2 & 7.28 & 0.075 \\
W2 & 6.86 & 6.65 & 6.755 & 0.105 \\
W3 & 7.2 & 7.21 & 7.205 & 0.005 \\
W4 & 7.16 & 7.2 & 7.18 & 0.02 \\
W5 & 7.13 & 7.18 & 7.155 & 0.025 \\
W6 & 6.8 & 6.9 & 6.85 & 0.05 \\
W7 & 6.89 & 6.9 & 6.895 & 0.005 \\
W8 & 7.21 & 7.65 & 7.43 & 0.22 \\
W9 & 7.73 & 7.89 & 7.81 & 0.08 \\
W10 & 7.45 & 7.33 & 7.30 & 0.06 \\
\hline
\end{tabular}




\subsection{Electrical conductivity}

In our study the conductivity values range from 575 to $954 \mu \mathrm{S} / \mathrm{cm}$ (Table 4). The maximum allowable value (MAV) is set to $2700 \mu \mathrm{S} / \mathrm{cm}$ according to Moroccan drinking water standards (Table 19), these values are still stable and below (VMA), but the high content of this parameter is explained by the high concentration of chloride ions (Table 5).

Table 4: Evolution of the conductivity of the water table Maâmora.

\begin{tabular}{|c|c|c|c|c|}
\hline Wells & February & March & Average $(\boldsymbol{\mu s} / \mathbf{c m})$ & SD \\
\hline W1 & 671 & 698 & 684.5 & 13.5 \\
W2 & 945 & 878 & 911.5 & 33.5 \\
W3 & 691 & 732 & 711.5 & 20.5 \\
W4 & 882 & 653 & 917.5 & 53.5 \\
W5 & 736 & 820 & 778 & 42 \\
W6 & 954 & 879 & 916.5 & 37.5 \\
W7 & 769 & 765 & 767 & 2 \\
W8 & 754 & 745 & 749.5 & 4.5 \\
W9 & 575 & 595 & 585 & 10 \\
W10 & 825 & 835 & 830 & 5 \\
\hline
\end{tabular}

\subsection{Chloride $\mathrm{Cl}^{-}$}

The chlorides are widespread in nature, generally in the form of sodium salts $(\mathrm{NaCl})$ and potassium $(\mathrm{KCl})$ and represent approximately $0.05 \%$ of the lithosphere. These are the oceans contain far the largest amount of chlorides in the environment. In our study the values of the concentration of chloride ions ranged from 81.65 to $237.85 \mathrm{mg} / \mathrm{L}$ (Table 5). According to Moroccan standards of potability of water, (Table 19) these values are still stable and lower than the maximum value set at $750 \mathrm{mg} / \mathrm{L}$, but the high content of this parameter is explained by the conductivity which is high and the geological rock formations that are contact with groundwater.

Table 5: Evolution of chlorides concentration in the water table Maâmora.

\begin{tabular}{|c|c|c|c|c|}
\hline Wells & February & March & Average (mg/l) & SD \\
\hline W1 & 81.65 & 106.5 & 94.075 & 12.425 \\
W2 & 102.95 & 102.95 & 102.95 & 0.00 \\
W3 & 195.25 & 220.1 & 207.675 & 12.425 \\
W4 & 152.65 & 205.9 & 179.275 & 26.625 \\
W5 & 85.2 & 85.2 & 85.2 & 0.00 \\
W6 & 213 & 237.85 & 225.425 & 12.425 \\
W7 & 152.65 & 166.85 & 159.75 & 7.1 \\
W8 & 113.6 & 124.25 & 118.925 & 5.325 \\
W9 & 92.3 & 95.85 & 94.075 & 1.775 \\
W10 & 134.9 & 134.9 & 134.9 & 0.00 \\
\hline
\end{tabular}




\subsection{Dissolved oxygen $\left(\mathrm{O}_{2}\right)$}

Dissolved oxygen varies during the study of 3.32 to $6.72 \mathrm{mg} / \mathrm{L}$ (Table 6). The maximum value is set between $5<\mathrm{O}_{2}<8 \mathrm{mg} \mathrm{O} / \mathrm{L}$ according to Moroccan standards for drinking water (Table 19).

Table 6: Evolution of the $\mathrm{O}_{2}$ concentration of the water table Maâmora.

\begin{tabular}{|c|c|c|c|c|}
\hline Wells & February & March & Average (mg/L) & SD \\
\hline W1 & 6.72 & 6.35 & 6.535 & 0.185 \\
W2 & 6.24 & 6.2 & 6.22 & 0.02 \\
W3 & 3.38 & 3.32 & 3.35 & 0.03 \\
W4 & 6.48 & 6.5 & 6.49 & 0.01 \\
W5 & 5.67 & 5.64 & 5.655 & 0.015 \\
W6 & 4.83 & 4.88 & 4.855 & 0.025 \\
\hline
\end{tabular}

\subsection{Oxidisability (with $\mathrm{KMnO}_{4}$ )}

The oxidisability by $\mathrm{KMnO}_{4}$ dissolved varies during the study from 1.0 to $3.2 \mathrm{mg} / \mathrm{L} \mathrm{O}_{2}$ (Table 7). The maximum allowable value of $\mathrm{O}_{2}$ is $5 \mathrm{mg} / \mathrm{L}$ by Moroccan standards (Table 19) for drinking water (ONEP [7]).

Table 7: Evolution of the oxidisability of the water table Maâmora.

\begin{tabular}{|c|c|c|c|c|}
\hline Wells & February & March & Average (mg $\left.\mathbf{~ O}_{\mathbf{2}} / \mathbf{L}\right)$ & SD \\
\hline W1 & 2 & 2.08 & 2.04 & 0.04 \\
W2 & 1 & 1.07 & 1.035 & 0.035 \\
W3 & 2.2 & 1.93 & 2.065 & 0.135 \\
W4 & 1.44 & 1.93 & 1.685 & 0.245 \\
W5 & 2 & 2 & 2 & 0.00 \\
W6 & 3 & 3.2 & 3.1 & 0.1 \\
\hline
\end{tabular}

\subsection{Turbidity (NTU)}

Turbidity varies during the study of 0.78 to 3.75 NTU (Table 8 ). The maximum value is 5 NTU by Moroccan standards for drinking water (Table 19). We find

Table 8: $\quad$ Change in the turbidity of the water table Maâmora.

\begin{tabular}{|c|c|c|c|c|}
\hline Wells & February & March & Average (NTU) & SD \\
\hline W1 & 1.03 & 1.25 & 1.14 & 0.11 \\
W2 & 1.08 & 1.54 & 1.31 & 0.23 \\
W3 & 0.78 & 1 & 0.89 & 0.11 \\
W4 & 1.8 & 1.58 & 1.69 & 0.11 \\
W5 & 0.87 & 0.984 & 0.927 & 0.057 \\
W6 & 3.75 & 3.54 & 3.645 & 0.105 \\
W7 & 2.35 & 2.24 & 2.295 & 0.055 \\
W8 & 2.8 & 2.87 & 2.835 & 0.035 \\
W9 & 3.65 & 3.75 & 3.7 & 0.05 \\
W10 & 3.25 & 3.22 & 3.235 & 0.015 \\
\hline
\end{tabular}


that $100 \%$ of the analyzed waters have turbidity levels below the maximum value and that are consistent with Moroccan standards, as these groundwater have natural filtration in the soil.

\subsection{Dry residue}

During our study, the dry residues values range from 0.0112 and $0.1246 \mathrm{mg} / \mathrm{L}$ (Table 9). The maximum value is set at $0.5 \mathrm{mg} / \mathrm{L}$, according to Moroccan standards of potability of water (Table 19). So these values are still lower than the maximum permissible value.

Table 9: $\quad$ Evolution of tenure Dry Residues in water table Maâmora.

\begin{tabular}{|c|c|c|c|c|}
\hline Wells & February & March & Average (mg/l) & SD \\
\hline W1 & 0.0553 & 0.0514 & 0.05335 & 0.00195 \\
W2 & 0.1063 & 0.1246 & 0.11545 & 0.00915 \\
W3 & 0.0608 & 0.0245 & 0.04265 & 0.01815 \\
W4 & 0.0157 & 0.0147 & 0.0152 & 0.0005 \\
W5 & 0.0112 & 0.0147 & 0.01295 & 0.0051 \\
W6 & 0.0624 & 0.0547 & 0.05855 & 0.00385 \\
\hline
\end{tabular}

\subsection{Alkalinity $\left(\mathrm{HCO}_{3}{ }^{-}\right)$}

The TAC assay is the ions $\mathrm{HO}^{-}, \mathrm{HCO}_{3}{ }^{-}$and $\mathrm{CO}_{3}{ }^{-}$present in the water, that is to say all of the basic species present. The alkali strength is a measurement of the water tenure of free carbonate and caustic alkali.

$\mathrm{HCO}_{3}{ }^{-}$water varies during the study from 4 to $6.2 \mathrm{meq} / \mathrm{L}$ (Table 10). The maximum value is $50 \mathrm{meq} / \mathrm{L}$ according to Moroccan standards of potability of water (Table 19). $\mathrm{HCO}_{3}{ }^{-}$is an indicator of the presence of ions carbonates, bicarbonates, hydroxides hardness of drinking water factor.

Table 10: Evolution of the concentration of $\mathrm{HCO}_{3}{ }^{-}$in water table Maâmora.

\begin{tabular}{|c|c|c|c|c|}
\hline Wells & February & March & Average (meq/L) & SD \\
\hline W1 & 4,2 & 4,3 & 4,25 & 0.05 \\
W2 & 5 & 5,4 & 5,2 & 0.2 \\
W3 & 5,3 & 5 & 5,2 & 0.15 \\
W4 & 4 & 4,6 & 4,3 & 0.1 \\
W5 & 4,3 & 4,4 & 4,3 & 0.05 \\
W6 & 4,5 & 5,6 & 5 & 0.55 \\
W7 & 5,4 & 5,5 & 5,5 & 0.1 \\
W8 & 4,9 & 4,9 & 4,9 & 0.05 \\
W9 & 5,4 & 5,4 & 5,4 & 0.1 \\
W10 & 6,2 & 6 & 6,1 & 0.1 \\
\hline
\end{tabular}




\subsection{Total Hardness (TH)}

TH of water varies during the study from 11.9 to $16.6 \mathrm{meq} / \mathrm{L}$ (Table 11). The maximum for Moroccan standards of potability is the value $50 \mathrm{meq} / \mathrm{L}$ (Table 19). $\mathrm{TH}$ is a factor indicating the presence of magnesium and calcium ions. Rock formations containing divalent metals $\left(\mathrm{Mg}^{2+}, \mathrm{Ca}^{2+}\right)$ are responsible for hardness.

Table 11: Evolution of the waters TH in water table Maâmora.

\begin{tabular}{|c|c|c|c|c|}
\hline Wells & February & March & Average (meq/L) & SD \\
\hline W1 & 15.6 & 14.3 & 14.95 & 0.65 \\
W2 & 13.7 & 13.4 & 13.55 & 0.15 \\
W3 & 14.2 & 12.2 & 13.2 & 1 \\
W4 & 13 & 14.2 & 13.6 & 0.6 \\
W5 & 12 & 13.5 & 12.75 & 0.75 \\
W6 & 15.5 & 16 & 15.75 & 0.25 \\
W7 & 13.3 & 13.6 & 13.45 & 0.15 \\
W8 & 13.00 & 13.1 & 13.05 & 0.05 \\
W9 & 11.9 & 12.2 & 12.05 & 0.15 \\
W10 & 16.6 & 16.2 & 16.4 & 0.2 \\
\hline
\end{tabular}

\subsection{Nitrate $\left(\mathrm{NO}_{3}{ }^{-}\right)$}

The nitrate content varies during the study from 1.245 to $51.55 \mathrm{mg} / \mathrm{L}$ (Table 12). The maximum value set at $50 \mathrm{mg} / \mathrm{l}$ according to Moroccan standards (Table 19) of potability of water (ONEP [7]). Although nitrates have no direct toxic effects except at high doses, the fact that they can give birth to nitrites leads to toxicity. Nitrate levels are high for W7 which exceed the Moroccan standards.

Table 12: Temporal variation of nitrate in water level of drilling studied water table Maâmora.

\begin{tabular}{|c|c|c|c|c|}
\hline Wells & February & March & Average (mg/L) & SD \\
\hline W1 & 47.95 & 45.65 & 46.8 & 1.15 \\
W2 & 2.02 & 2.21 & 2.115 & 0.095 \\
W3 & 1.459 & 1.245 & 1.352 & 0.107 \\
W4 & 32.15 & 33.25 & 32.7 & 0.55 \\
W5 & 4.56 & 4.73 & 4.645 & 0.085 \\
W6 & 36.48 & 37.22 & 36.85 & 0.37 \\
W7 & 51.55 & 51 & 51.275 & 0.275 \\
W8 & 26.15 & 22.45 & 24.3 & 1.85 \\
W9 & 4.34 & 4.54 & 4.44 & 0.1 \\
W10 & 5.13 & 4.73 & 4.93 & 0.2 \\
\hline
\end{tabular}

\subsection{Nitrite $\left(\mathrm{NO}_{2}^{-}\right)$}

The nitrite content varies during the study of 0.00 to $0.032 \mathrm{mg} / \mathrm{L}$ (Table 13). The VMA nitrite is set at $0.5 \mathrm{mg} / \mathrm{L}$ according to Moroccan standards (Table 19). 
Table 13: Evolution of the concentration of nitrite in the water table Maâmora.

\begin{tabular}{|c|c|c|c|c|}
\hline Wells & February & March & Average (mg/L) & SD \\
\hline W1 & 0 & 0 & 0 & 0 \\
W2 & 0.001 & 0.0012 & 0.0011 & 0.001 \\
W3 & 0 & 0 & 0 & 0 \\
W4 & 0.003 & 0.0001 & 0.00155 & 0.00145 \\
W5 & 0 & 0.002 & 0.001 & 0.001 \\
W6 & 0.0014 & 0.0013 & 0.00135 & 0.00005 \\
W7 & 0.021 & 0.032 & 0.0265 & 0.0055 \\
W8 & 0.019 & 0.012 & 0.0155 & 0.0035 \\
W9 & 0.0132 & 0.0135 & 0.01335 & 0.00015 \\
W10 & 0.052 & 0.057 & 0.0323 & 0.0025 \\
\hline
\end{tabular}

\subsection{Ammonium $\left(\mathrm{NH}_{4}{ }^{+}\right)$}

In our study the ammonium values range from 0.00 to $0.35 \mathrm{mg} / \mathrm{L}$ (Table 14). The maximum value is set at $0.5 \mathrm{mg} / \mathrm{L}$ according to Moroccan standards of potability (Table 19).

Table 14: Evolution of ammonium concentration in water table Maâmora.

\begin{tabular}{|c|c|c|c|c|}
\hline Wells & February & March & Average (mg/L) & SD \\
\hline W1 & 0 & 0.01 & 0.005 & 0.005 \\
W2 & 0.11 & 0.13 & 0.12 & 0.01 \\
W3 & 0.01 & 0.12 & 0.065 & 0.055 \\
W4 & 0.31 & 0.01 & 0.16 & 0.15 \\
W5 & 0.12 & 0.1 & 0.11 & 0.01 \\
W6 & 0.23 & 0.35 & 0.29 & 0.06 \\
W7 & 0.045 & 0.042 & 0.0435 & 0.0015 \\
W8 & 0.039 & 0.036 & 0.0375 & 0.0015 \\
W9 & 0.040 & 0.041 & 0.0405 & 0.0005 \\
W10 & 0.041 & 0.037 & 0.039 & 0.002 \\
\hline
\end{tabular}

\subsection{Sulfate $\left(\mathrm{SO}_{4}{ }^{-}\right)$}

Sulfate varies during the study between 11.58 and $21.2 \mathrm{mg} / \mathrm{L}$ (Table 15). The maximum value is set at $400 \mathrm{mg} / \mathrm{L}$. by Moroccan standards of potability of water (Table 19), so these values are still well below the maximum allowable value. This can be justified by the presence of very low sulfate levels in the soil and groundwater in the study area (ONEP [7]).

\subsection{Boron}

Boron varies between 0.00 and $0.026 \mathrm{mg} / \mathrm{L}$ (Table 16). The maximum value is set at $0.3 \mathrm{mg} / \mathrm{L}$, according to Moroccan standards of potability (Table 19). Therefore these values are still well below the authorized maximum value. 
Table 15: Evolution of the concentration of sulfate ion in water table Maâmora.

\begin{tabular}{|c|c|c|c|c|}
\hline Wells & February & March & Average (mg/L) & SD \\
\hline W1 & 19.7 & 20.4 & 20.05 & 0.35 \\
W2 & 20.1 & 21.2 & 20.65 & 0.55 \\
W3 & 19.8 & 20.7 & 20.25 & 0.45 \\
W4 & 19.6 & 20.3 & 19.95 & 0.35 \\
W5 & 20 & 20.6 & 20.3 & 0.3 \\
W6 & 19.9 & 20.2 & 20.05 & 0.15 \\
W7 & 15.04 & 14.56 & 14.8 & 0.24 \\
W8 & 13.67 & 14.32 & 13.995 & 0.325 \\
W9 & 14.34 & 15.41 & 14.875 & 0.535 \\
W10 & 11.66 & 11.58 & 11.62 & 0.04 \\
\hline
\end{tabular}

Table 16: Evolution of the concentration of boron in water table Maâmora.

\begin{tabular}{|c|c|c|c|c|}
\hline Wells & February & March & Average (mg/L) & SD \\
\hline W1 & 0.001 & 0.00 & 0.0005 & 0.0005 \\
W2 & 0.002 & 0.001 & 0.0015 & 0.0005 \\
W3 & 0.001 & 0.001 & 0.001 & 0.00 \\
W4 & 0.0013 & 0.0014 & 0.00135 & 0.00005 \\
W5 & 0.00 & 0.00 & 0.00 & 0.00 \\
W6 & 0.0003 & 0.0013 & 0.0008 & 0.0005 \\
W7 & 0.0026 & 0.0032 & 0.0029 & 0.0003 \\
W8 & 0.0027 & 0.0026 & 0.0265 & 0.0005 \\
W9 & 0.0001 & 0.0001 & 0.0001 & 0.00 \\
W10 & 0.0004 & 0.0003 & 0.00035 & 0.00005 \\
\hline
\end{tabular}

\subsection{Fluoride ( $\left.\mathbf{F}^{-}\right)$}

During our study of fluoride the values range from 0.18 and $0.26 \mathrm{mg} / \mathrm{L}$ (Table 17). The maximum value is fixed at $1.5 \mathrm{mg} / \mathrm{L}$, by Moroccan standards of potability (Table 19).

Table 17: Evolution of the fluoride concentration in water table Maâmora.

\begin{tabular}{|c|c|c|c|c|}
\hline Wells & February & March & Average (mg/L) & SD \\
\hline W1 & 0.2 & 0.21 & 0.205 & 0.005 \\
W2 & 0.21 & 0.23 & 0.22 & 0.01 \\
W3 & 0.18 & 0.19 & 0.185 & 0.005 \\
W4 & 0.23 & 0.24 & 0.235 & 0.005 \\
W5 & 0.2 & 0.2 & 0.2 & 0.00 \\
W6 & 0.25 & 0.26 & 0.255 & 0.005 \\
\hline
\end{tabular}




\subsection{Silicate}

In our study the values of silicate ranged from 0.236 and $22.08 \mathrm{mg} / \mathrm{L}$ (Table 18). The maximum value is $100 \mathrm{mg} / \mathrm{L}$, according to Moroccan standards of potability.

Table 18: Evolution of the silicate concentration in water table Maâmora.

\begin{tabular}{|c|c|c|c|c|}
\hline Wells & February & March & Average (mg/L) & SD \\
\hline W1 & 22.08 & 21.00 & 21.54 & 0.54 \\
W2 & 0.254 & 0.236 & 0.245 & 0.009 \\
W3 & 0.469 & 0.495 & 0.482 & 0.013 \\
W4 & 0.728 & 0.706 & 0.717 & 0.011 \\
W5 & 0.834 & 0.817 & 0.8255 & 0.0085 \\
W6 & 0.347 & 0.356 & 0.3515 & 0.0045 \\
W7 & 0.495 & 0.467 & 0.481 & 0.014 \\
W8 & 0.914 & 0.932 & 0.923 & 0.009 \\
W9 & 19.46 & 19.53 & 19.495 & 0.035 \\
W10 & 0.347 & 0.378 & 0.3625 & 0.0135 \\
\hline
\end{tabular}

\subsection{Bacteriological analyzes of water boreholes}

Bacteriological analyzes of water from 10 wells studied reveal the complete absence of coliform bacteria: Escherichia coli, Enterococci and Total germs because catchment areas are protected. This is consistent with the guidance of ONEP [7].

The results of the physico-chemical analysis presented in this work showed that the $\mathrm{pH}$, temperature, organic matter and sulfates can be considered eligible and have no impact on water quality. Thus, the average $\mathrm{pH}$ values (7.8), temperature $\left(21.2^{\circ} \mathrm{C}\right)$ and sulfate $(21 \mathrm{mg} / \mathrm{L})$ are consistent with the standards of supply waters REEM [1]. These results are in agreement with those obtained on the waters of groundwater M'nasra Maâmora (Bricha et al. [9] and Belksiri Gharb Akhiar [10]). The variation of the concentration of nitrates found between different wells may be related to the heterogeneity between different physical environments. For Saadi et al. [11], the large spatial variability of nitrate at Maâmora study area is due to the surface texture and lithology. However, the proportion of wells nitrate is low; the high proportion of nitrates can be caused by the use of chemical fertilizers in agriculture. The heavy rainfall and lack of vegetation cover contribute to the rapid leaching of nitrates to groundwater Maâmora. Similarly, Zilliox et al. [12] found that the winter period is the critical phase of leaching of excess nitrogen in groundwater in France in the Rhine valley, because of the lack of vegetation and the impact of heavy rainfall. Moreover, in the water Maâmora there are no indicators of fecal contamination, in agreement with those found in Marrakech. The comparison between the Moroccan and international standards and data carried out on samples of raw water of Maâmora shows that values of our studies are lower than the standards of Morocco, WHO, France, England and Tunisia (Table 19). 
Table 19: Comparison of water table Maâmora with Standards.

\begin{tabular}{|c|c|c|c|c|c|c|}
\hline Parameters & $\begin{array}{l}\text { Maamora } \\
\text { maximum }\end{array}$ & Moroccan & $\begin{array}{c}\text { WHO } \\
2007 \\
\end{array}$ & $\begin{array}{c}\text { French } \\
1993 \\
\end{array}$ & $\begin{array}{c}\text { English } \\
2010 \\
\end{array}$ & \begin{tabular}{|c|} 
Tunisian \\
1993 \\
\end{tabular} \\
\hline $\mathrm{T}^{\circ} \mathrm{C}$ & 21,9 & 25 & 25 & 25 & 25 & 25 \\
\hline $\mathrm{pH}$ & 7,89 & $6,5-8,5$ & $6,5-8,5$ & $6,5-8,5$ & $6,5-8,5$ & $6,5-8,5$ \\
\hline E C $\mu \mathrm{s} / \mathrm{cm}$ & 954 & 2700 & 2500 & 2500 & 2500 & 2500 \\
\hline Turbidity NTU & 3,75 & 5 & 5 & 5 & 4 & 5 \\
\hline T.H mg/l & $16,6 \mathrm{meq}$ & $50 \mathrm{meq}$ & 500 & 500 & 200 & 500 \\
\hline $\mathrm{HCO}_{3}{ }^{-} \mathrm{mg} / \mathrm{l}$ & $6,2 \mathrm{meq}$ & $50 \mathrm{meq}$ & 400 & 400 & 250 & 400 \\
\hline $\mathrm{NO}_{3}{ }^{-} \mathrm{mg} / \mathrm{l}$ & 51,55 & 50 & 50 & 50 & 50 & 50 \\
\hline $\mathrm{NO}_{2}^{-} \mathrm{mg} / \mathrm{l}$ & 0,032 & 0,5 & 0,5 & 0,1 & 0,50 & 0,1 \\
\hline $\mathrm{SO}_{4}^{-} \mathrm{mg} / \mathrm{l}$ & 21,2 & 400 & 250 & 250 & 250 & 250 \\
\hline $\mathrm{CL}^{-} \mathrm{mg} / \mathrm{l}$ & 237,85 & 750 & 250 & 250 & 250 & 250 \\
\hline $\mathrm{NH}_{4}^{+} \mathrm{mg} / \mathrm{l}$ & 0,35 & 0,5 & 0,5 & 0,5 & 0,3 & 0,5 \\
\hline $\mathrm{O}_{2} \mathrm{mg} / \mathrm{l}$ & 6,72 & $5-8$ & $5-8$ & $5-8$ & $5-7$ & $5-8$ \\
\hline Oxidisability & 3,2 & $5 \mathrm{meq}$ & 5 & 5 & - & 5 \\
\hline Boron mg/l & 0,026 & 0,3 & 0,3 & 0,01 & 1,0 & 0,01 \\
\hline $\mathrm{F}^{-} \mathrm{mg} / \mathrm{l}$ & 0,26 & 1,5 & 1,5 & 1,5 & 1,5 & 1,5 \\
\hline $\mathrm{SiO}_{2} \mathrm{mg} / 1$ & 22,08 & 100 & 100 & 100 & - & 100 \\
\hline $\begin{array}{c}\text { Dry Residue } \\
\mathrm{mg} / \mathrm{l}\end{array}$ & 0,1246 & 0,5 & 0,5 & 1500 & - & 1500 \\
\hline
\end{tabular}

\section{Conclusion}

The study of these waters and analysis concluded that the threats to the resources of various types of chemicals, human activity, agriculture is very serious. Therefore, the preventive aspect should focus more on the regular monitoring of water quality and control of pollution sources that threaten the water. The implementation and management of groundwater to ensure the availability of water in sufficient quantity and of adequate quality for the benefit of all users in accordance with the aspirations of economic development, harmonious and environmentally sustainable.

\section{References}

[1] REEM Rapport sur l'Etat de l'Environnement du Maroc Ed, 2, p.296, 2001.

[2] Laferriere, M.J., Minville, J., Lavoie, J. \& Payment, P., L'industrie porcine et les risques reliés à la santé humaine. Bull. Information Santé Environnem, Québec, 7 (2), pp. 1-4, 1996.

[3] Organisation Mondiale de la Santé (OMS) (WHO), Charte d'Ottawa pour la promotion de la santé, Copenhagen: Bureau régional de l'Europe, 1986.

[4] Zouhri, L. \& Carlier, E., Hydrochemical Features of a Coastal Aquifer, Morocco. Journal of Environmental Hydrology, 10, Paper 2, May 2002. 
[5] Rodier, J., L'analyse de l'eau: eaux naturelles, résiduaires, de mer: physico-chimie, bactériologie et biologie, ed. Dunod, Paris, France, 8, $1383 p, 1996$.

[6] Duncun, D.B., Multiple rang and F tests. Biometrics, 11, pp. 1-42, 1955.

[7] ONEP, Alimentation en eau potable, Menaces de pollution. 1999.

[8] Elbouqdaoui, K., Aachib, M., Blaghen, M., \& Kholtei, S., Modélisation pollution nitrates nappe Berrechid. Afrique Sciences, 5(1), pp. 99-113, 2009.

[9] Bricha, S., Ounine, K., Oulkheir, S., Elhaloui, N., \& Attarassi, B., Etude de la qualité physicochimique et bactériologique de la nappe phréatique M'nasra Maâmora Maroc. Afrique Sciences, 3(3), pp. 391-404, 2007.

[10] Akhiar S., Caractérisation des eaux souterraines de la ville de Mechraa BelKsiri. Mémoire Master, Faculté des Sciences Kénitra, 2009.

[11] Saadi, Z., Maaslouhi, A., Zeraouli, M. \& Gaudet, J.P., Analyse et modélisation des variations saisonnières des concentrations en nitrates dans les eaux souterraines de la nappe Mnasra, Maroc. C. R. Acad. Sci., Sér. 2, Sci. Terre Planètes, 329(8), pp. 579-586, 1999.

[12] Zilliox, L., Schenc, C., Kobus, H. \& Huwe, B., Pollution par les nitrates: Quels remèdes? Supplément, La Recherche Suppl. les enjeux de l'agriculture en Europe, 227, pp. 18-21, 1990. 